\title{
Effect of feeding different sources of selenium on growth performance and antioxidant status of broilers
}

by Woods, S.L., Sobolewska, S., Rose, S.P., Whiting, I.M., Blanchard, A., Ionescu, C., Bravo, D. and Pirgozliev, V.

Copyright, publisher and additional information: this is the authors' accepted manuscript. The published version is available via Taylor \& Francis

Please refer to any applicable terms of use of the publisher.

DOI: https://doi.org/10.1080/00071668.2020.1716301

Harper Adams University 


\section{Effect of feeding different sources of selenium on growth performance and antioxidant status of broilers}

\section{S.L. Woods, S. Sobolewska, S.P. Rose, I.M. Whiting, A. Blanchard, C. Ionescu, D. Bravo \& V. Pirgozliev}

To cite this article: S.L. Woods, S. Sobolewska, S.P. Rose, I.M. Whiting, A. Blanchard, C. Ionescu, D. Bravo \& V. Pirgozliev (2020): Effect of feeding different sources of selenium on growth performance and antioxidant status of broilers, British Poultry Science, DOI: 10.1080/00071668.2020.1716301

To link to this article: https://doi.org/10.1080/00071668.2020.1716301

Accepted author version posted online: 17 Jan 2020.

Submit your article to this journal

山ll Article views: 38

Q View related articles ¿

View Crossmark data \lceil 
Publisher: Taylor \& Francis \& British Poultry Science Ltd

Journal: British Poultry Science

DOI: $10.1080 / 00071668.2020 .1716301$

Effect of feeding different sources of selenium on growth performance and antioxidant status of broilers

S.L. WOODS ${ }^{1}$, S. SOBOLEWSKA ${ }^{1}$, S.P. ROSE ${ }^{1}$, I.M. WHITING ${ }^{1}$, A. BLANCHARD ${ }^{2}$, C. IONESCU ${ }^{2}$, D. BRAVO ${ }^{2}$, AND V. PIRGOZLIEV $^{1}$

${ }^{1}$ National lnstitute of Poultry Husbandry, Harper Adams University, TF10 8NB, UK

${ }^{2}$ Pancosma SA, Le Grand-Saconnex, Switzerland

Corresponding author: S.L. Woods

Email: slwoods@harper-adams.ac.uk.

The National Institute of Poultry Husbandry, Harper Adams University, Newport, UK.

Abstract

1. This study was conducted to determine the effect of different sources of selenium (Se) on deposition, apparent metabolisable energy (AME), growth performance and antioxidant status of broilers, measured as Se content in liver and breast tissues and glutathione peroxidase (GSH-Px) in blood, when used in 0-35 d broiler chicken diets.

2. A total of 200 male Ross 308 broilers were used in the feeding trial, which comprised two dietary phases, a starter from 0 to $21 \mathrm{~d}$ and finisher from 21 to $35 \mathrm{~d}$ of age. Four treatments with 10 replications each were used. A control diet (C) was formulated that was sufficient in protein and energy (230 and $215 \mathrm{~g} / \mathrm{kg}$ of crude protein and 12.67 and 13.11 
$\mathrm{MJ} / \mathrm{kg}$ of metabolisable energy, respectively), for both phases, but contained background Se only from the feed ingredients. The first treatment diet (IS) was made from the C diet supplemented with $10.35 \mathrm{~g} / \mathrm{t}$ inorganic source of elemental Se in both feed phases. The third treatment (SY) was the control diet supplemented with $136.36 \mathrm{~g} / \mathrm{t}$ selenised yeast (Sacchromyces cerevisiae) in both feed phases. A fourth treatment (SS) was the C diet supplemented with $0.666 \mathrm{~g} / \mathrm{t}$ sodium selenite an inorganic source of Se in both starter and finisher diets.

4. Birds fed the SY diet consumed less and weighed less than those fed IS or $\mathrm{C}(\mathrm{P}<0.05 ; 0$ $35 \mathrm{~d}$ of age), but there was no difference compared to birds fed SS diets. There were no differences in FCR or dietary AME between broilers fed different Se sources. All diets containing supplementary Se increased concentrations in the liver and breast muscle, and for GSH-Px levels in blood compared to birds fed the $\mathrm{C}$ diet $(\mathrm{P}<0.001)$. Birds fed SY diets had greater Se levels in liver and breast tissues compared to birds fed any of the other diets $(\mathrm{P}<0.001)$.

5. Diets supplemented with Se had variable effects on broiler growth performances and antioxidant status. Feeding Se from a yeast source has higher transfer into tissues. Feeding different sources and levels of Se to birds in a more challenging situation to induce oxidative stress may bring more conclusive results.

Key words: Chickens, selenium, feed intake, weight gain, antioxidant status.

\section{INTRODUCTION}

The main aims of intensive broiler production systems are to produce healthy birds that mature quickly. Finding alternative ways to improve growth, immunity and general overall health to enable birds to mature efficiently have been the focus of much research (Patterson 
and Burkholder, 2003; Surai, 2006). Initially, studies have focussed on improving production by non-antibiotic means, including the application of prebiotics, probiotics, organic acids, plant extracts and enzymes (Griggs and Jacob, 2005; Pirgozliev et al., 2014, 2015a, Ahmed et al., 2017). However, recent reports showed that feeding dietary antioxidants can improve bird antioxidant status, bird health and subsequent performance (Surai, 2002; Karadas et al., 2014; Pirgozliev et al., 2018).

Selenium is an important antioxidant and is significant in many major metabolic pathways, including antioxidant defence systems (Surai et al., 2016), immunity (Arthur et al., 2003) and thyroid hormone metabolism (Brown and Arthur, 2001). As the poultry industry continues to evaluate effective Se sources which can improve bird health and productivity (Surai et al., 2018), although there is some inconsistency in published literature. For example, some authors have reported that the source of Se can significantly affect bioavailability and that organic Se is better at improving performance variables, including feed intake (FI), weight gain (WG) and feed conversion ratio (FCR) compared to inorganic forms (Yang et al., 2012). However, in other studies FI and FCR were not affected by the source, but rather by the concentration of Se (Oliveira et al., 2014).

The significance of Se is mainly due to its role as a component of important antioxidant enzymes, such as glutathione peroxidase (GSH-Px), the regulation of which is crucially dependent on dietary Se intakes (Surai, 2002). However, there are inconsistent findings as to whether an increase in dietary organic Se increases liver GSH-Px levels (Chen et al., 2014), or makes no difference to its activity in plasma (Payne and Southern, 2005); in breast muscle (Leeson et al., 2008), or in the liver (Heindl et al., 2010). Choct et al. (2004), found that birds supplemented with inorganic Se had higher GSH-Px levels than those fed organic Se supplements, but Skrivan et al. (2012), found GSH-Px increased irrespective of Se source. Although an increase in hepatic antioxidant status is related to 
improved dietary available energy (Pirgozliev et al., 2015b), there is a lack of information on the effect of dietary Se on energy.

In view of these conflicting results, the main aim of this study was to investigate how different sources of Se affect broiler performance, including daily FI, WG and FCR, antioxidant status (measured by GSH-Px in blood) and Se concentration in breast and liver tissues. Dietary apparent metabolisable energy (AME) was measured to determine whether there were any differences between or relationships with Se sources.

\section{MATERIALS AND METHODS}

\section{Animals and diets}

The study was approved by Harper Adams University Research Ethics Committee. In total, 200, one-day-old male Ross 308 broiler chicks were obtained from a commercial hatchery (Cyril Bason Ltd, Craven Arms, UK). On arrival, chicks were individually weighed, the heaviest and lightest birds were removed, and five birds were placed each in 40 raisedfloor pens $(0.6 \times 0.6 \mathrm{~m}$ solid floor area). Each pen was equipped with a separate feeder and drinker and the floor was covered with absorptive litter material. After the first week, the litter material was replaced every three days. The room temperatures were kept at $32^{\circ} \mathrm{C}$ on arrival and gradually reduced to $20^{\circ} \mathrm{C}$ at day 21 , following the breeder's recommendations (Aviagen Ltd, Edinburgh, UK). A standard lighting programme for broilers was used, decreasing from 23:1 (hours light: dark) from one-d-old to 18:6 at $7 \mathrm{~d}$ of age, which was maintained until the end of the study. The relative humidity was maintained between 50 to $70 \%$.

A total of four diets were used, in two dietary phases: a starter-grower phase from 0 to 21 $\mathrm{d}$, and a finisher phase from 21 to $35 \mathrm{~d}$. Two basal diets containing wheat and soybean, as the main raw ingredients, were mixed in proportions which varied slightly between the two 
dietary phases (Table 1). All diets were fed as mash. For the starter-grower period, the basal diet consisted of $60.65 \%$ wheat, and $31.70 \%$ soybean meal, with calcuated $22.99 \%$ crude protein and $12.67 \mathrm{MJ} / \mathrm{kg} \mathrm{ME}$. For the finishing period, the basal diet consisted of $62.95 \%$ wheat, and $28.0 \%$ soybean meal, with $21.49 \%$ crude protein of and $13.11 \mathrm{MJ} / \mathrm{kg}$ ME. The basal diets for both phases were split into four equal parts and supplemented with different sources of selenium. Both, starter and finisher control diets $(\mathrm{C})$ were not supplemented, and only contained background levels of Se from the raw materials (Table 1). Diet 2 (IS) was supplemented with.35 g/t inorganic, elemental source of Se. Diet 3 (SY) was supplemented with $136.36 \mathrm{~g} / \mathrm{t}$ selenised yeast, an organic source derived from Sacchromyces cerevisiae. Diet 4 (SS) was supplemented with $0.666 \mathrm{~g} / \mathrm{t}$ sodium selenite, inorganic source. All three Se sources were provided by Pancosma SA, Switzerland. Each diet allocated to randomised pens $(\mathrm{n}=10)$. Feed and water were fed ad libitum.

Table 1 here

\section{Sample collection}

Between d 17 and 21 of the trial, the solid floor of each pen was replaced with a wire mesh and all excreta was collected during this period, oven dried at $60^{\circ} \mathrm{C}$ and then milled through $0.75 \mathrm{~mm}$ screen. The feed intake during this period was determined. After day 21, the solid floor was re-installed in each pen and the starter-grower diet was changed to finisher diet. At the end of the study (35 d), one bird per pen was selected at random, electrically stunned and blood samples removed into $6 \mathrm{ml}$ heparin coated tubes (Midmeds Ltd, Hertford, UK) from the jugular vein. The livers and approximately $80 \mathrm{~g}$ of the left breast from each bird were removed and stored at $-80^{\circ} \mathrm{C}$ for further analysis. 


\section{Laboratory analysis}

Dry matter (DM) in feed and excreta samples were determined by drying samples in a forced draft oven to a constant weight (AOAC 2000; method 934.01). The gross energy (GE) of feed and excreta samples were determined in a bomb calorimeter (Model 6200; Parr Instrument Co., Moline, IL) with benzoic acid used as the standard. Dietary AME was determined based on the method published by Pirgozliev et al. (2006). Selenium concentrations in the liver and breast samples were determined by inductively coupled plasma emission spectrometry (Optima 4300 DV Dual View ICP-OE spectrometer, PerkinElmer, Beaconsfield, UK), as described by Tanner et al. (2002). Haemoglobin was performed based on the method used by Drabkin (1950), and glutathione peroxidase was determined using Ransel GSH-Px kit (Randox Laboratories Ltd., UK) that employed the method of Paglia and Valentine (1967).

\section{Statistical analysis}

Data was statistical compared using a randomised block ANOVA (Genstat $18^{\text {th }}$ release 3.22 for Windows, IACR, Rothamsted, Hertfordshire, UK). When $\mathrm{P}<0.05$, Duncan's multiple range test was used to separate differences in the means.

\section{RESULTS}

Birds remained healthy throughout the experiment, with the exception of one dead bird in the first week. The analysed chemical composition of the basal diets are shown in Table 1, and the analysed protein and fat contents of diets were close to the calculated values. The determined Se in the control diets was the background level from dietary components. The determined Se values in diets were more variable, but within expected margins (Table 1). The liver weight and the Se contents of breast and liver are presented in Table 2. There Accepted for publication 1 November 2019 
were no differences in liver weight between treatments. All birds fed supplementary Se irrespective of source, had higher total hepatic Se (mg) concentration compared with the C fed birds $(\mathrm{P}<0.001)$. Birds fed SY, had the highest Se concentration in the liver $(\mathrm{P}<0.001)$, and breast $(\mathrm{P}<0.001)$, but there were no differences between birds fed the two sources of inorganic Se (IS and SS) in either tissue (Table 2).

Table 2 here

Haemoglobin $(\mathrm{Hb})$, blood GSH-Px and dietary AME are presented in Table 3. The highest $\mathrm{Hb}$ was found in birds fed the IS diets and lowest in birds fed $\mathrm{SY}(\mathrm{P}<0.05)$. There was no difference between the levels of $\mathrm{Hb}$ in birds fed IS and C diets, and no difference between the SY and SS diets (Table 3).

Table 3 here

Activity of GSH-Px in blood was not affected by the source of Se. The C diet had the lowest GSH-Px versus birds fed Se supplemented diets $(\mathrm{P}<0.001)$. There were no differences in AME between any of the diets (Table 3). The coefficient of variation (CV\%) for Se in breast and liver tissue (Table 2) and Hb, GSH-Px and AME (Table 3) were small and showed no variation between treatments.

The overall live weight of the birds at 21 and $35 \mathrm{~d}$ age was 816 and $2031 \mathrm{~g}$, respectively (data not shown). Broiler growth performance variables, including FI, WG and FCR are presented in Table 4. The CV\% were within the expected range (Aviagen Ltd., Edinburgh, UK). Although there were small differences between the starter-grower and finisher periods regarding growth performance variable responses, for ease of discussion the 
authors paid attention primarily on the data obtained from the overall experimental period from 0 to $35 \mathrm{~d}$ age.

Table 4 here

From 0 to 35 d, the highest FI was seen in birds fed IS diet, and lowest in birds fed SY diet $(\mathrm{P}<0.05)$. There was no difference in FI between the C, IS and SS fed birds, but SY consumed less than $\mathrm{C}$ and IS fed birds $(\mathrm{P}<0.05$; Table 4).

From 0 to $35 \mathrm{~d}$, the highest WG was seen in birds fed the C diet compared to birds fed SY which had the lowest WG $(\mathrm{P}<0.05)$, but this was not significant when compared to birds fed the IS or SS diets. There were no differences in WG between birds fed C, IS and SS diets. There were no differences in FCR for any of the studied periods (Table 4).

\section{DISCUSSION}

The weight of the birds was slightly lower than the breeder's recommendation, but was in agreement with a previous study feeding mash diet to broilers (Pirgozliev et al., 2016). The metabolism of Se is complex and differs between the sources (Ganther, 1986). The form affects Se absorption, retention and subsequent utilisation. In this study, two inorganic and one organic sources of Se were used. SS is absorbed by simple diffusion across the gut wall and is easily incorporated into selenoproteins, but SY is absorbed by active transport (Suzuki and Ogra, 2002). As SY predominantly contains selenomethionine (SeMet), it is not used in the synthesis of selenoproteins, but is directly incorporated into proteins through the replacement of methionine and so is more readily available for tissue deposition (Wolffram et al., 1989). It can be converted to selenocysteine (SeCys), which subsequently may be cleaved to form selenide, which is absorbed by active transport (Oliveira et al., 2014). This allows animals to build up reserves in tissues, especially Accepted for publication 1 November 2019 
muscles, which can then be used during stressful conditions to improve antioxidant defences. The current results showed that the highest Se in breast and liver tissues were found in birds fed SY diet, which implied that organic Se diet was assimilated and incorporated more readily compared to the inorganic and $\mathrm{C}$ diets. These findings have been confirmed by others (Chen et al., 2014). Rajashree et al. (2014a) found that organic Se contributed to better egg productivity and higher Se accumulation and antioxidant status in eggs. However, the current results differed from those reported by Kinal et al. (2012) who found no differences in Se content in breast and liver from birds fed diets containing either organic or inorganic Se. They reported that, although tenderness was better in those birds fed organic Se, birds that were fed inorganic Se had better breast tissue colour, taste, flavour and juiciness, although these factors were not tested in the current study. In another study by Mohapatra et al. (2014), Se in breast tissue increased with higher concentrations of added dietary Se. Varying Se concentration of the diets in the current experiment was not tested, but should be considered in the future, as some authors (Choct et al., 2004: Yoon et al., 2007) have found an inverse relationship between FI and diet level.

Selenium retention in tissues has important implications for the health of poultry and their progeny, and beneficial effects have been shown to last several weeks after hatching (Pappas et al., 2008). Increasing Se in eggs and poultry meat could be beneficial for poultry consumers ingesting Se enriched poultry and for producers wishing to promote Se enriched 'functional foods' to retailers and consumers. Functional foods are increasingly seen as satisfying a growing demand in consumers, not just for safe nutrition, but for promoting human health (Reilly, 1998). Se is increasingly being seen as a functional food and recently, in a human study by $\mathrm{Ju}$ et al. (2017), Se was found to have positive health benefits in coronary heart disease development by reducing oxidative stress and inflammation and enhancing the protection of coronary arteries in cardiac disease. Low Se status has been linked to increased mortality, poor immune function and reductions in 
cognition in humans (Rayman et al., 2012). However, when considering the beneficial health effects of Se, it is not just the total amount consumed, but the form of Se which affects its absorption and bioavailability (Pedrero and Madrid, 2009). The natural form of Se added in poultry diets is organic but, for the last 20 years, the most common dietary supplemented Se source has been inorganic, which is less expensive is absorbed differently, as previously discussed (Surai and Fisinin, 2014). This has important implications to consumers who ingest nutritionally enriched Se meat, as studies have shown that different Se sources affect subsequent deposition in tissues and that organic forms improve meat quality and concentration in meat by $97 \%$ compared to a control, and by $27 \%-61 \%$ versus inorganic (Rajashree et al., 2014b). Hence, the type of Se is important for health and oxidative status in the bird and for those who ingest nutritionally enriched produce (Fisinin et al., 2009). Organic SY sources are noted for their ability to deposit higher levels of Se in breast tissue, as shown in a recent study by Van Beirendonck et al. (2016). They reported that SY (with higher SeMet) had greater Se deposition in breast tissue compared with a lower SeMet source, and birds fed L-SeMet had the greatest Se concentration in breast tissue. Therefore, the bioavailability of the different Se species is an important consideration when reviewing the effect of Se on both broiler and human health.

In a recent study by Bakirdere et al. (2018), broilers fed inorganic Se had more total Se in breast tissue compared to those fed a control or SY organic diets, but the organic fed birds had the higher bioavailable SeMet versus the other two groups.

To date, there have been 25 selenoproteins identified and all have different properties. One of these proteins is GSH-Px, which exerts its affect by its antioxidant activity by the removal and detoxification of hydrogen peroxide and lipid hydroperoxides (Papp et al., 2007). The regulation of this important Se-containing enzyme is dependent on dietary 
intake of Se (Surai, 2002), but researchers have reported conflicting results as to whether its activity is increased or decreased by different Se sources.

Chen et al. (2014), found that birds fed diets supplemented with organic Se had higher liver and plasma GSH-Px levels compared with birds fed inorganic Se sources. In contrast, others reported that birds fed diets supplemented with inorganic Se supplements had higher GSH-Px levels than those fed diets containing organic Se (Choct et al., 2004). However, others found that, when comparing GSH-Px levels from birds fed organic versus inorganic Se supplemented diets, there was no difference, whether the GSH-Px was measured in plasma (Payne and Southern, 2005); breast muscle (Leeson et al., 2008), or the liver (Heindl et al., 2010).

Haemoglobin $(\mathrm{Hb})$ is carried by erythrocytes $(\mathrm{RBC})$, which are particularly susceptible to oxidative stress because they contain a high level of polyunsaturated fatty acids in their membrane (Cicha et al., 1999). GSH-Px is integrated into erythrocytes during erythropoiesis (in chickens, the RBC life span is $28-35$ days) and so is commonly used as a marker for determining long term Se status and as an oxidative stress marker (Hafeman et al., 1974). A high GSH-PX status is considered to indicate higher antioxidant status, and conversely, lower GSH-Px would be expected in higher oxidative stress situations (Surai, 2006). This was confirmed in the current study, which showed that all diets supplemented with Se (irrespective of source), had higher blood GSH-Px levels versus the control. This agreed with Arai et al. (1994) and Wang and Xu (2009) who found that supplementing diets with Se increased GSH-Px levels. However, Cichoski et al. (2012), reported that GSH-Px was not affected by the source or concentration of dietary Se. As GSH-Px is a Secontaining enzyme, it would be expected that diets supplemented with Se would result in higher levels of GSH-Px. Arai et al. (1994) showed a 28.45\% increase in GSH-Px levels when comparing diets supplemented with Se to unsupplemented feed, and Wang and Xu (2009) showed an increase of $188 \%$ when comparing different Se sources to a control 
which had no added Se. In the current study, the increase was higher at $243 \%$, although the Se level in the control diets could have been a contributing factor, for example, the Se in the Wang et al. (2009) study was $0.05 \mathrm{mg} / \mathrm{kg}$, which was well below the NRC recommended allowance of $0.15 \mathrm{mg} / \mathrm{kg}$. In the current study, the basal level of Se in the $\mathrm{C}$ diet was $0.134 \mathrm{mg} / \mathrm{kg}$, i.e. above the minimum NRC supplementation recommendations. However this was still much less than the Se in the other diets in the study $(1.6 ; 3.5$; and 4.2 times lower in IS; SY and SS respectively). Hence, it was expected that the GSH-Px activity in birds fed C diet would be significantly less compared to GSH-Px in birds fed the Se supplemented diets. In addition to the level of Se supplemented in the C diets, source could be a factor, as bioavailability is affected by the Se source. The organic source used in the current study was SY, but in the study by Wang and Xu (2009), the organic Se source was nano-Se. Nano-Se technology is reported to have higher adsorption and increased catalytic activity (Cai et al., 2012). However, there is limited research in broilers of nanoSe gut absorption and tissue retention (Hu et al., 2012). Another reason the GSH-Px activity was higher in the current study could be attributed to the fact that only blood GSHPx, and not liver and breast tissue GSH-Px was measured. In contrast, the opposite was reported by Bakhshalinejad et al. (2018), who determined levels of GSH-Px in broiler thigh muscle and liver tissues. They found significant increases in GSH-Px levels in liver and thigh muscle from birds fed organic Se in the form of DL selenomethionine (DL SeMet) compared with those fed other types of Se, both organic and inorganic. The reason for this could be due to differences in dietary formulation, rearing conditions and the source of Se used in these studies (nano-Se, DL SeMet, SS and SY), which could affect absorption and bioavailability.

The level of $\mathrm{Hb}$ in broilers in the current study was higher than the expected range seen in previous studies (Maxwell et al., 1990; Makeri et al., 2017). Possible reasons for this include differences in broiler strains and better overall nutritional status in birds in the 
current study. The finding that $\mathrm{Hb}$ was higher in birds fed IS diet, which was inorganic, compared to birds fed diets containing SY and SS, but not higher than in birds fed C was unexpected, as the higher $\mathrm{Hb}$ levels in the control did not mirror the lower blood GSH-Px levels. A possible explanation for this could be that, although GSH-Px is present in the $\mathrm{Hb}$ when levels of Se are low, it is not easily released into the circulation. Similar results were found by Choct et al. (2004), who found that SS increased GSH-Px levels more than SY. There were differences in FI and WG in the $\mathrm{C}$ group as well as for birds fed the different sources of Se. The opposite was found by Yoon et al. (2007) and Chen et al. (2014), who found no differences in growth performance between birds fed diets containing SY and SS. However, Yang et al. (2012) and Mohapatra et al. (2014) reported differences in performance between different Se sources. But, conversely, in their studies, they reported that dietary organic Se improved WG and FI when compared to the inorganic form, which was the opposite of what was currently found. Contrary to expectations, the results in the current study demonstrated that diets supplemented with Se did not increase WG, and the $\mathrm{C}$ diet, which contained the least amount of Se, had one of the largest overall gains in weight versus the other treatment diets. On reflection, this was not a surprise, as the $\mathrm{C}$ diet contained Se levels of $0.134 \mathrm{mg} / \mathrm{kg}$, just below $\mathrm{NRC}$ recommended guidelines of 0.15 $\mathrm{mg} / \mathrm{kg}$, which were evidently sufficient enough to satisfy Se requirements for growth, so did not affect FI or WG under normal broiler production conditions.

In the current study, the lack of difference in FCR between the diets agreed with some (Chadio et al., 2015), although others (Yang et al., 2012) found that organic Se sources (SY at $0.3 \mathrm{ppm}$ ) improved FCR compared to inorganic forms (SS at $0.3 \mathrm{ppm}$ ). They reported that organic Se reduced survival rate, which was attributed to a faster growth rate, causing cardiac overload. Differences in survival rate was not found in the present study. Although an increase in hepatic antioxidant status is reflected with improved dietary available energy (Pirgozliev et al., 2015b), limited studies have reported comparisons for 
AME in diets supplemented with Se. In the current study, no differences were found between the broilers fed different Se sources with regard to AME, which agreed with Choct et al. (2004). As AME is a measurement of the available energy in carbohydrates, fats and proteins (Leeson and Summers, 2001) it was expected that different sources of Se would not greatly impact AME.

\section{CONCLUSIONS}

Feeding different types of Se affected subsequent Se concentration in the meat but not growth performance variables. This was not unduly surprising, as there was sufficient Se in the $\mathrm{C}$ diet to enable the birds to grow under normal husbandry practices. However, further work should be undertaken to determine if diets supplemented with different Se sources affect performance when broilers are raised in less than optimal environmental conditions.

\section{ACKNOWLEDGEMENTS}

Special thanks to Richard James and Rosalind Crocker for their technical support.

\section{FUNDING}

This work was supported by Pancosma and Harper Adams University.

\section{REFERENCES}


AHMED, S.T., S.Y., KO, and C.J. YANG. 2017. "Improving the Nutritional Quality and Shelf Life of Broiler Meat by Feeding Diets Supplemented with Fermented Pomegranate." British Poultry Science 58 (6): 694-703. doi.org/10.1080/00071668.2017.1363870. ARAI, T., M., SUGAWARA, T., SAKO, S., MOTOYOSHI, T., SHIMURA, N., TSUTSUI, and T. KONNO. 1994. "Glutathione Peroxidase Activity in Tissues of Chickens Supplemented with Dietary Selenium." Comparative Biochemistry and Physiology 107: 245-248. doi.org/10.1016/0300-9629(94)90301-8.

ARTHUR, J.R., R.C., McKENZIE, and G.J. BECKETT. 2003. "Selenium in the Immune System.” Journal of Nutrition 133: 1457-1459. doi.org/10.1093/jn/133.5.1457S.

AVIAGEN 2018. "Ross 308 Broiler: Nutrition Specifications." Accessed September 2019. http://en.aviagen.com/assets/Tech_Center/Ross_Broiler/Ross308BroilerNutritionSpecs201 4-EN.p

BAKHSHALINEJAD, R., R. A. M., KAKHKI, and E. ZOIDIS. 2018. "Effects of Dietary Sources and Levels of Selenium Supplements on Growth Performance, Antioxidant Status and Immune Parameters in Ross 308 Broiler Chickens.” British Poultry Science 59 (1): 8191. doi.org/10.1080/00071668.2017.1380296.

BAKIRDERE, S., M., VOLKAN, and O.Y. ATAMAN. 2018. "Selenium Speciation in Chicken Breast Samples from Inorganic and Organic Selenium Fed Chickens Using High Performance Liquid Chromatography-Inductively Coupled Plasma-Mass Spectrometry." Journal of Food Composition and Analysis 71: 28-35. doi.org/10.1016/j.jfca.2018.05.005.

BROWN, K.M., and J.R. ARTHUR. 2001. "Selenium, Selenoproteins and Human Health: a Review." Public Health Nutrition 4: 593-599. doi.org/10.1079/PHN2001143.

CAI, S.J., C.X., WU, L.M., GONG, T., SONG, H., WU, and L.Y. ZHANG. 2012. "Effects of Nano-Selenium on Performance, Meat Quality, Immune Function, Oxidation 
Resistance, and Selenium Content in Broilers.” Poultry Science 91: 2532-2539. doi.org/10.3382/ps.2012-02160.

CHAdiO, S.E., A.C., PAPPAS, A., PAPANAstastasatas, D., PANTElia, A., DARDAMANI, K., FERGEROS, and G. ZERAS. 2015. "Effects of High Selenium and Fat Supplementation on Growth Performance and Thyroid Hormones Concentration of Broilers." Journal of Trace Elements in Medicine and Biology 29: 202-207. doi.org/10.1016/j.jtemb.2014.09.010.

CHEN, G., J., WU, and C. LI. 2014. "Effect of Different Selenium Sources on Production Performance and Biochemical Parameters of Broilers." Journal of Animal Physiology and Animal Nutrition 98: 747-754. https://doi.org/10.1111/jpn.12136.

CHOCT, M., A.J., NAYLOR, and N. REINKE. 2004. "Selenium Supplementation Affects Broiler Growth Performance, Meat Yield and Feather Coverage." British Poultry Science 45 (5): 677-683. doi.org/10.1080/00071660400006495.

CICHA, I., Y., SUZUKI, N., TATEISHI, and N. MAEDA. 1999. "Rheological Changes in Human Red Blood Cells under Oxidative Stress." Pathophysiology 6: 103-110. doi.org/10.1016/S0928-4680(99)00005-X.

CICHOSKI, A.J., R.B., ROTTA, G., SCHEUERMANN, A., CUNHA JUNIOR, and J.S. BARIN. 2012. "Investigation of Glutathione Peroxidase Activity in Chicken Meat under Different Experimental Conditions." Food Science and Technology 32 (4): 661-667. doi.org/10.1590/S0101-20612012005000107.

DRABKIN, D.L., 1950. "The Distribution of the Chromoproteins, Hemoglobin, Myoglobin, and Cytochrome C, in the Tissues of Different Species, and the Relationship of the Total Content of Each Chromoprotein to Body Mass." Journal of Biological Chemistry 182 (1): 317-334. http://www.jbc.org/content/182/1/317.full. 
FISININ, V.I., T.T., PAPAZYAN, and P.F. SURAI. 2009. "Producing Selenium-Enriched Eggs and Meat to Improve the Selenium Status of the General Population." Critical Reviews in Biotechnology 29 (1): 18-28. doi.org/10.1080/07388550802658030.

GANTHER, H.E., 1986. "Pathways of Selenium Metabolism Including Respiratory Excretory Products." Journal of the American College of Toxicology 5 (1): 1-5. doi.org/10.3109/10915818609140731.

GRIGGS, J.P., and J.P. JACOB. 2005. “Alternatives to Antibiotics for Organic Poultry Production.” Journal of Applied Poultry Research 14: 750-756. doi.org/10.1093/japr/14.4.750.

HAFEMAN, D.G., R.A., SUNDE, and W.G. HOEKSTRO. 1974. "Effect of Dietary Selenium on Erythrocyte and Liver Glutathione Peroxidase in the Rat." The Journal of Nutrition 104 (5): 580-587. doi.org/10.1093/jn/104.5.580.

HEINDL, J., Z., LEDVINKA, M., ENGLMAJEROVA, L., ZITA, and E. TUMOVA. 2010. "The Effect of Dietary Selenium Sources and Levels on Performance, Selenium Content in Muscle and Glutathione Peroxidase Activity in Broiler Chickens." Czechoslovakian Journal of Animal Science 55 (12): 572-578. https://www.agriculturejournals.cz/publicFiles/32641.

HU, C.H., LI, Y.L., XIONG, L., ZHANG, H.M., SONG, J. and M.S. XIA. 2012.

“Comparative Effects of Nano Elemental Selenium and Sodium Selenite on Selenium Retention in Broiler Chickens." Animal Feed Science and Technology 177 (3-4): 204-210. doi:10.1016/j.anifeedsci.2012.08.010.

JU, W., X., LI, Z., LI, G.R., WU, X.F., FU, X.M., TANG, X.Q., ZHANG, and X.B. GAO. 2017. "The Effect of Selenium Supplementation on Coronary Heart Disease: a Systematic Review and Meta-analysis of Randomised Controlled Trials." Journal of Trace Elements in Medicine and Biology 44: 8-16. doi.org/10.1016/j.jtemb.2017.04.009. 
KARADAS, F., V., PIRGOZLIEV, S.P., ROSE, D., DIMITROV, O., ODUGUWA, and D. BRAVO. 2014. "Dietary Essential Oils to Improve the Hepatic Antioxidants of Broiler Chickens.” British Poultry Science 55 (3): 329-334.

doi.org/10.1080/00071668.2014.891098.

KINAL, S., B., KROL, and W. TRONINA. 2012. "Effect of Various Selenium Sources on Selenium Bioavailability, Chicken Growth Performance, Carcass Characteristics and Meat Composition of Broiler Chickens." Electronic Journal of Polish Agriculture 15 (1). http://www.ejpau.media.pl/articles/volume15/issue1/art-07.

LEESON, S., and J.D. SUMMERS. 2001. Scott's Nutrition of the Chicken. $4^{\text {th }}$ ed. Ontario, Canada. University Books.

LEESON, S., H., NAMKUNG, L., CASTON, S., DUROSOY, and P. SCHLEGEL. 2008. "Comparison of Selenium Levels and Sources and Dietary Fat Quality in Diets for Broiler Breeders and Layer Hens.” Poultry Science 87: 2605-2612. doi.org/10.3382/ps.200800174.

MAKERI, H. K., J. O., AYO, T., ALUWONG, and N.S. MINKA. 2017. "Daily Rhythms of Blood Parameters in Broiler Chickens Reared under Tropical Climate Conditions. Journal of Circadian Rhythms 15: 5. doi:10.5334/jcr.151.

MAXWELL, M.H., G. W. ROBERTSON, S. SPENCE and C. C.

McCORQUODALE. 1990. "Comparison of Haematological Values in Restricted- and $A d$ Libitum fed Domestic Fowls: Red blood cell characteristics,” British Poultry Science 31 (2): 407-413. doi10.1080/00071669008417271.

MOPHAPATRA, P., R.K., SWAIN, S.K., MISHRA, T., BEHERA, P., SWAIN, N.C., BEHURA, G., SAHOO, K., SETHY, B.P., BHOL, and K. DHARMA. 2014. "Effects of Dietary Nano-selenium Supplementation on the Performance of Layer Grower Birds." Asian Journal of Animal and Veterinary Advances 9 (10): 641-652. doi10.3923/ajava.2014.641.652. 
NATIONAL RESEARCH COUNCIL (NRC).1994. Nutrient Requirements of Poultry. $9^{\text {th }}$ ed. Washington, USA. National Academy Press.

OLIVEIRA, T.F.B., D.F.R., RIVERA, F.R., MESQUITA, H., BRAGA, E.M., RAMSO, and A.G. BERTECHINI. 2014. "Effect of Different Sources and Levels of Selenium on Performance, Meat Quality, and Tissue Characteristics of Broilers.” Journal of Applied Poultry Research 23: 15-22. doi.org/10.3382/japr.2013-00761.

PAGLIA, D.E., and W.N. VALENTINE. 1967. "Studies on the Quantitative and Qualitative Characterization of Erythrocyte and Glutathione Peroxidase.” Translational Research 70 (1): 158-169. https://www.translationalres.com/article/0022-2143(67)900765.

PAPP, L.V., LU, J., HOLMGREN, A. and K.K. KHANNA. 2007. "From Selenium to Selenoproteins: Synthesis, Identity, and Their Role in Human Health.” Antioxidants and Redox Signalling 9 (7): 775-806. doi.org/10.1089/ars.2007.1528.

PAPPAS, A.C., E.V., ZOIDIS, P., SURAI, and G. ZERVAS. 2008. "Selenoproteins and Maternal Nutrition." Comparative Biochemistry and Physiology Part B: 361-372. doi.org/10.1016/j.cbpb.2008.08.009.

PATTERSON, J.A., and K.M. BURKHOLDER. 2003. "Application of Prebiotics and Probiotics in Poultry." Poultry Science 82: 627-631. doi.org/10.1093/ps/82.4.627.

PAYNE, R.L., and L.L. SOUTHERN. 2005. "Comparison of Inorganic and Organic Selenium Sources for Broilers.” Poultry Science 84: 898-902. doi.org/10.1093/ps/84.6.898. PEDERO, Z., and Y. MADRID. 2009. "Novel Approaches for Selenium Speciation in Foodstuffs and Biological Specimens: a review." Analytica Chimica Acta 634 (2): 135152. doi.org/10.1016/j.aca.2008.12.026.

PIRGOZLIEV, V.R., S.P., ROSE, and P.S. KETTLEWELL. 2006. "Effect of Ambient Storage of Wheat Samples on Their Nutritive Value for Chickens." British Poultry Science 47 (3): 342-349. doi.org/10.1080/00071660600741750. 
PIRGOZLIEV, V., D., BRAVO, and S.P. ROSE. 2014. "Rearing Conditions Influence Nutrient Availability of Plant Extracts Supplemented Diets When Fed to Broiler Chickens." Journal of Animal Physiology and Animal Nutrition 98 (4): 667-671. doi.org/10.1111/jpn.12119.

PIRGOZLIEV, V., D., BRAVO, M.W., MIRZA, and S.P. ROSE. 2015a. "Growth Performance and Endogenous Losses of Broilers Fed Wheat-Based Diets With and Without Essential Oils and Xylanase Supplementation." Poultry Science, 94 (6): 12271232. doi.org/10.3382/ps/peu017.

PIRGOZLIEV, V., F., KARADAS, S.P., ROSE, A., FERNANDES BECCACCIA, M.W., MIRZA, and A.M. AMERAH. 2015b. "Dietary Xylanase Increases Hepatic Vitamin E Concentration of Chickens Fed Wheat Based Diet." Journal of Animal and Feed Sciences 24 (1): 80-84. doi.org/10.22358/jafs/65656/2015.

PIRGOZLIEV, V., M.W., MIRZA and S.P. ROSE. 2016. "Does the Effect of Pelleting Depend on the Wheat Sample When Fed to Chickens?" Animal 10 (4): 571-577. doi.org/10.1017/S1751731115002311.

PIRGOZLIEV, V., S.C., MANSBRIDGE, S.P., ROSE, H.S., LILLEHOJ, and D. BRAVO. 2018. "Immune Modulation, Growth Performance, and Nutrient Retention in Broiler Chickens Fed a Blend of Phytogenic Feed Additives." Poultry Science 0: 1-8. doi.org/10.3382/ps/pey472.

RAJASHREE, K., T., MUTHUKUMAR, and N. KARTHIKEYAN. 2014a. "Comparative Study of the Effects of Organic Selenium on Hen Performance and Productivity of Broiler Breeders.” British Poultry Science $55 \quad$ (3): $\quad$ 367-374. doi.org/10.1080/00071668.2014.921663.

RAJASHREE, K., T., MUTHUKUMAR, and N. KARTHIKEYAN. 2014b. "Influence of Inorganic and Organic Selenium Sources on Broiler Performance and Meat Quality." 
Iranian Journal of Applied Poultry Science 4 (1): 151-157. https://www.researchgate.net/profile/Muthukumar_Thangavelu/publication/262179854. RAYMAN, M.P. 2012. “Selenium and Human Health.” The Lancet 379 (9822): 12561268. doi.org/10.1016/S0140-6736 (11)61452-9.

REILLY, C., 1998. "Selenium: A New Entrant into the Functional Food Arena." Trends in Food Science \& Technology 9 (3): 114-118. doi.org/10.1016/S0924-2244(98)00027-2.

SKRIVAN, M., M., MAROUNEK, M., ENGLMAIEROVA, and E. SKRIVANOVA. 2012. "Influence of Dietary Vitamin C and Selenium, Alone and in Combination, on the Composition and Oxidative Stability of Meat in Broilers." Food Chemistry 130: 660-664. doi.org/10.1016/j.foodchem.2011.07.103.

SURAI, P. F., 2002. "Selenium in Poultry Nutrition: Antioxidant Properties, Deficiency and Toxicity." World Poultry Science Journal $58 \quad$ (3): 333-347. doi.org/10.1079/WPS20020026.

Surai, P. F., 2006. Selenium in Nutrition and Health. Nottingham, Nottingham University Press.

SURAI, P.F. and V.I. FISININ. 2014. "Selenium in Poultry Breeder Nutrition: An Update." Animal Feed Science and Technology 191: 1-15. doi.org/10.1016/j.anifeedsci.2014.02.005.

SURAI, P.F., V.I., FISININ, and F. KARADAS. 2016. “Antioxidant Systems in Chick Embryo Development. Part 1. Vitamin E, Carotenoids and Selenium." Animal Nutrition 2 (1): 1-11.

doi.org/10.1016/j.aninu.2016.01.001.

SURAI, P.F., I.I., KOCHISH, V.I., FISININ, and O.A. VELICHKO. 2018. "Selenium in Poultry Nutrition: From Sodium Selenite to Organic Selenium Sources." Poultry Science 55 (2) : 79-93. doi.org/10.2141/jpsa.0170132. 
SUZUKI, K.T., and Y. OGRA. 2002. "Metabolic Pathway for Selenium in the Body." Food Additives and Contaminants 19: 974-983. doi.org/10.1080/02652030210153578.

TANNER, S.D., V.I., BARANOV, and D.R. BANDURA. 2002. "Reaction Cells and Collison Cells for ICP-MS: a Tutorial Review." Spectrochimica Acta, Part B Atomic Spectroscopy 57 (9): 1361-1452. doi.org/10.1016/S0584-8547 (02)00069-1.

VAN BEIRENDONCK, S., B., DRIESSEN, M., ROVERS, L., SEGERS, A., RUTTENS, and G. DU LAING. 2016. "Relation between Selenomethionine Content in Dietary Selenium Sources and Selenium Deposition in Broiler Muscle Tissue.” In The Proceedings of XXV World's Poultry Congress (63). World's Poultry Science Association. doi.org/ 10.3920/978-90-8686-830-8.

WANG, Y.B., and B.H. XU. 2009. "Effect of Different Selenium Source (Sodium Selenite and Selenium Yeast) on Broiler Chickens." Animal Feed Science and Technology 144: 306-314. doi.org/10.1016/j.anifeedsci.2007.10.012.

WOLFFRAM, S. B., GRENACHER, B., and R. SCHARRER. 1989. "Transport of Selenoamino Acids and Their Sulphur Analogues across the Intestinal Brush Border Membrane.” Journal of Nutrition 119: 706-712. doi.org/10.1093/jn/119.5.706.

YANG, Y.R., F.C., MENG, P., WANG, Y.B., JIANG, Q.Q., YIN, J., CHANG, R.Y., ZUO, Q.H., ZHENG, and J.X. LIU. 2012. "Effect of Organic and Inorganic Selenium Supplementation on Growth Performance, Meat Quality and Antioxidant Properties of Broilers." African Journal of Biotechnology $11 \quad$ (12): 3031-3036. doi.org/10.5897/AJB11.3382.

YOON, I., T.M., WERNER, and J.M. BUTLER. 2007. "Effect of Source and Concentration of Selenium on Growth Performance and Selenium Retention in Broiler Chickens."

Poultry Science 86 (6): 727-730. doi.org/10.1093/ps/86.4.727. 
Table 1. Ingredient composition of the broiler experimental diets (as fed).

\begin{tabular}{|c|c|c|}
\hline Ingredients $\mathrm{g} / \mathrm{kg}$ & & Finisher \\
\hline Wheat & 606.5 & 629.5 \\
\hline Soybean meal & 317.0 & 280.0 \\
\hline Vegetabl & 35.0 & 50.0 \\
\hline & 3.0 & 3.0 \\
\hline DL Methionine & 3.7 & 3.9 \\
\hline Lysine $\mathrm{HCl}$ & 1.8 & 1.6 \\
\hline Limestone & 10.00 & 10.00 \\
\hline Dicalcium Phosphate & 18.0 & 17.0 \\
\hline Vitamin Mineral premix ${ }^{1}$ & 5.0 & 5.0 \\
\hline
\end{tabular}


Calculated values (as fed)

Crude protein $(\mathrm{N} \times 6.25) \mathrm{g} / \mathrm{kg}$

229.9

214.9

Crude oil g/kg

46.5

61.4

$\mathrm{ME}, \mathrm{MJ} / \mathrm{kg}$

Calcium g/kg

Av Phosphorus g/kg

4.5

Determined values

Dry matter $(\mathrm{g} / \mathrm{kg})$

878

890

Crude protein $(\mathrm{N} x$ x 6.25$) \mathrm{g} / \mathrm{kg}$

223.5

212.2

Crude oil g/kg

44.3

62.0

Gross energy $(\mathrm{MJ} / \mathrm{kg})$

16.60

Selenium

3

${ }^{1}$ The vitamin and mineral premix contained vitamins and trace elements to meet requirements specified by NRC (1994), except experimental diets which varied in selenium. The premix provided (units per $\mathrm{kg} /$ diet): cholecalciferol $125 \mu \mathrm{g}$; retinol $3600 \mu \mathrm{g}$, $\alpha$-tocopherol $30 \mathrm{mg}$; riboflavin $10 \mathrm{mg}$; pantothenic acid $15 \mathrm{mg}$; cobalt $0.5 \mathrm{mg}$; molybdenum $0.5 \mathrm{mg}$; cyanocobalamin $30 \mathrm{mg}$; pyridoxine $3 \mathrm{mg}$; thiamine $3 \mathrm{mg}$; folic acid $1.5 \mathrm{mg}$; niacin $60 \mathrm{mg}$; biotin $0.25 \mathrm{mg}$; iodine $1 \mathrm{mg}$; copper $10 \mathrm{mg}$; iron $20 \mathrm{mg}$; manganese $100 \mathrm{mg}$; zinc $80 \mathrm{mg}$.

$\mathrm{C}=$ control; $\mathrm{IS}=$ elemental Se; $\mathrm{SY}=$ selenised yeast $; \mathrm{SS}=$ sodium selenite ${ }^{2} \mathrm{C}=0.113 \mathrm{mg} / \mathrm{kg} \mathrm{DM} ; \mathrm{IS}=\mathrm{C}+0.454 \mathrm{mg} / \mathrm{kg} \mathrm{DM} ; \mathrm{SY}=\mathrm{C}+0.438 \mathrm{mg} / \mathrm{kg} \mathrm{DM} ; \mathrm{SS}=\mathrm{C}+0.527$ $\mathrm{mg} / \mathrm{kg} \mathrm{DM}$. 
${ }^{3} \mathrm{C}=0.134 \mathrm{mg} / \mathrm{kg} \mathrm{DM} ; \mathrm{IS}=\mathrm{C}+0.487 \mathrm{mg} / \mathrm{kg} \mathrm{DM} ; \mathrm{SY}=\mathrm{C}+0.465 \mathrm{mg} / \mathrm{kg} \mathrm{DM} ; \mathrm{SS}=\mathrm{C}+0.564$ $\mathrm{mg} / \mathrm{kg} \mathrm{DM}$.

Table 2. The effect of dietary selenium (Se) source on broiler liver weight and selenium (Se) content in liver and breast tissue.

\begin{tabular}{lcccc}
\hline \multicolumn{1}{c}{ Diet } & Liver weight & Se liver & Liver & Se breast \\
& $(\mathrm{g})$ & $(\mathrm{mg} / \mathrm{kg}$ wet & total Se & $(\mathrm{mg} / \mathrm{kg}$ wet weight $)$ \\
& & weight $)$ & $(\mathrm{mg})$ & $0.113^{\mathrm{a}}$ \\
\hline $\mathrm{C}$ & 43.4 & $0.375^{\mathrm{a}}$ & $0.016^{\mathrm{a}}$ & $0.151^{\mathrm{b}}$ \\
$\mathrm{IS}$ & 44.8 & $0.660^{\mathrm{b}}$ & $0.029^{\mathrm{b}}$ & $0.274^{\mathrm{c}}$ \\
$\mathrm{SY}$ & 43.3 & $0.735^{\mathrm{c}}$ & $0.032^{\mathrm{b}}$ & $0.149^{\mathrm{b}}$ \\
$\mathrm{SS}$ & 44.9 & $0.648^{\mathrm{b}}$ & $0.029^{\mathrm{b}}$ & 0.0030 \\
$\mathrm{SEM}$ & 1.85 & 0.0149 & 0.0011 & 5.5 \\
$\mathrm{CV} \%$ & 13.2 & 7.8 & 13.7 & $<0.001$ \\
$\mathrm{P}$ & 0.882 & $<0.001$ & $<0.001$ & \\
\hline
\end{tabular}

Means within a column not sharing a common superscript are significantly different.

$\mathrm{C}=$ control $0.134 \mathrm{mg} / \mathrm{kg} ; \mathrm{IS}=\mathrm{C}+0.487 \mathrm{mg} / \mathrm{kg}$ elemental Se; $\mathrm{SY}=\mathrm{C}+0.465 \mathrm{mg} / \mathrm{kg}$ selenised yeast and $\mathrm{SS}=\mathrm{C}+0.564 \mathrm{mg} / \mathrm{kg}$ sodium selenite. 10 replicates per diet.

Table 3. The effect of dietary selenium (Se) source on broiler blood haemoglobin $(\mathrm{Hb})$, blood glutathione peroxidase (GSH-Px) and apparent metabolisable energy (AME) determined at 35 days of age.

\begin{tabular}{|c|c|c|c|}
\hline Diet & $\mathrm{Hb}(\mathrm{g} / \mathrm{l})$ & $\begin{array}{c}\text { GSH-Px } \\
\text { blood } \\
(\mathrm{U} / \mathrm{g} \mathrm{HB})\end{array}$ & $\begin{array}{c}\mathrm{AME} \\
(\mathrm{MJ} / \mathrm{kg} \mathrm{DM})\end{array}$ \\
\hline
\end{tabular}




\begin{tabular}{lccc}
\hline $\mathrm{C}$ & $172^{\mathrm{ab}}$ & $45^{\mathrm{a}}$ & 14.85 \\
IS & $182^{\mathrm{b}}$ & $147^{\mathrm{b}}$ & 15.01 \\
SY & $151^{\mathrm{a}}$ & $167^{\mathrm{b}}$ & 14.91 \\
SS & $160^{\mathrm{a}}$ & $149^{\mathrm{b}}$ & 14.66 \\
$\mathrm{SEM}$ & 7.0 & 12.7 & 0.108 \\
$\mathrm{CV} \%$ & 13.4 & 31.6 & 2.5 \\
$\mathrm{P}$ & 0.029 & $<0.001$ & 0.239 \\
\hline
\end{tabular}

Means within a column not sharing a common superscript are significantly different.

$\mathrm{C}=$ control $0.134 \mathrm{mg} / \mathrm{kg} ; \mathrm{IS}=\mathrm{C}+0.487 \mathrm{mg} / \mathrm{kg}$ elemental $\mathrm{Se} ; \mathrm{SY}=\mathrm{C}+0.465 \mathrm{mg} / \mathrm{kg}$ selenised yeast and $\mathrm{SS}=\mathrm{C}+0.564 \mathrm{mg} / \mathrm{kg}$ sodium selenite. 10 replicates per diet.

Table 4. The effect of dietary selenium (Se) source on broiler daily feed intake (FI), weight gain (WG) and feed conversion ratio (FCR) for the different growing periods.

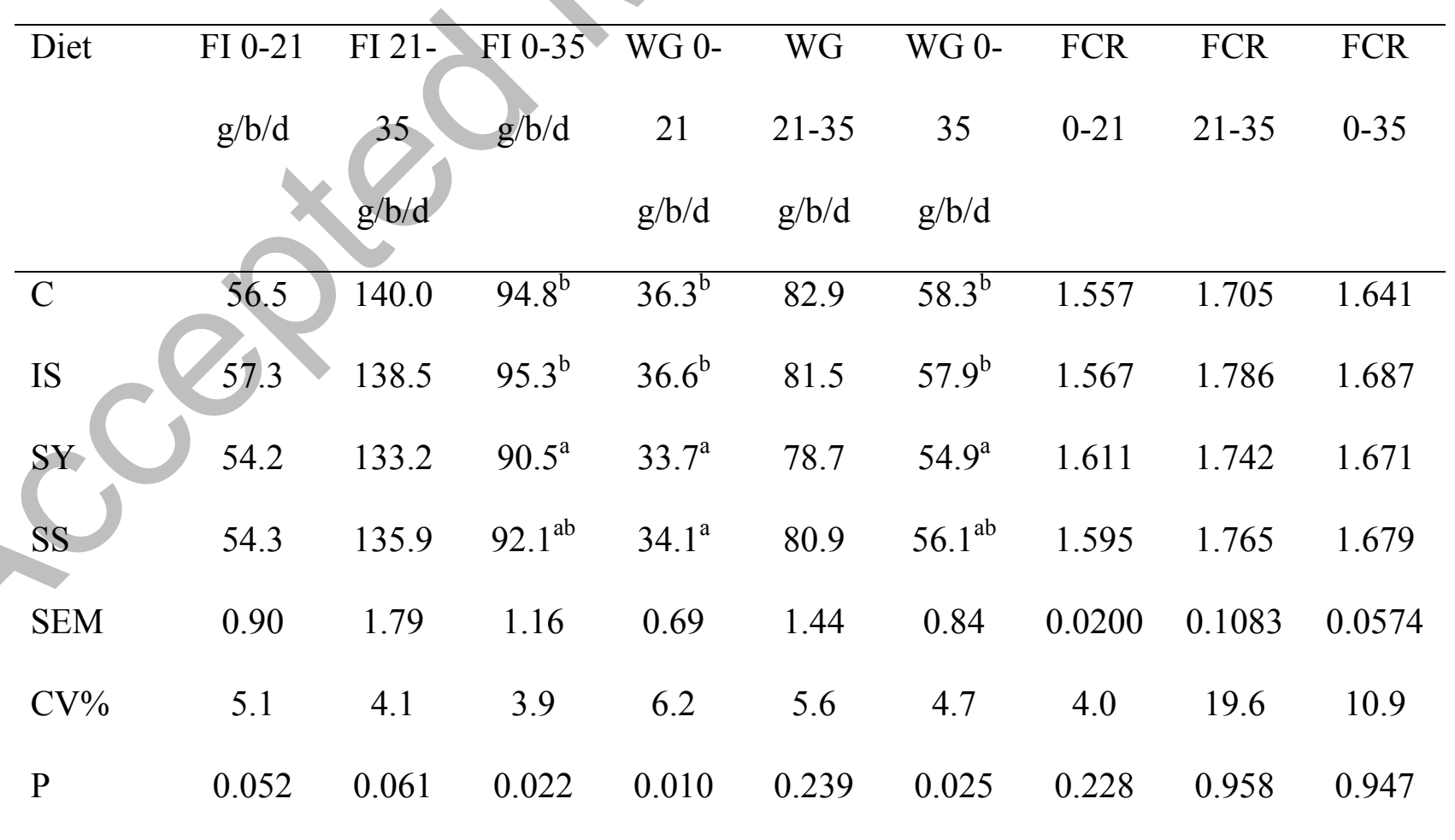

Means within a column not sharing a common superscript are significantly different. 
$\mathrm{C}=$ control $0.134 \mathrm{mg} / \mathrm{kg} ; \mathrm{IS}=\mathrm{C}+0.487 \mathrm{mg} / \mathrm{kg}$ elemental $\mathrm{Se} ; \mathrm{SY}=\mathrm{C}+0.465 \mathrm{mg} / \mathrm{kg}$ selenised yeast and $\mathrm{SS}=\mathrm{C}+0.564 \mathrm{mg} / \mathrm{kg}$ sodium selenite. 10 replicates per diet. 